\title{
Planning, Accountability and Reporting of Village Financial Management in Indonesia
}

\author{
Bill Pangayow ${ }^{*}$ Kurniawan Patma \\ Department of Accounting, Faculty of Economic and Business, Cenderawasih University, Indonesia
}

Received January 29, 2021; Revised March 13, 2021; Accepted April 9, 2021

\section{Cite This Paper in the following Citation Styles}

(a): [1] Bill Pangayow, Kurniawan Patma, "Planning, Accountability and Reporting of Village Financial Management in Indonesia," Universal Journal of Accounting and Finance, Vol. 9, No. 2, pp. 197 - 203, 2021. DOI: 10.13189/ujaf.2021.090208.

(b): Bill Pangayow, Kurniawan Patma (2021). Planning, Accountability and Reporting of Village Financial Management in Indonesia. Universal Journal of Accounting and Finance, 9(2), 197 - 203. DOI: 10.13189/ujaf.2021.090208.

Copyright $\mathrm{C} 2021$ by authors, all rights reserved. Authors agree that this article remains permanently open access under the terms of the Creative Commons Attribution License 4.0 International License

\begin{abstract}
Good village financial management is very important in improving good governance in the village. The large amount of funds given to villages requires managers to improve the quality of the financial management process so that they can be trusted by the community. This study aims to examine the effect of financial management processes in the form of planning, implementation and reporting on Accountability, which is an element of good governance. The research sample was 78 officers in four villages in Sentani District, Jayapura Regency, Indonesia. The indicators used to measure the planning, implementation, reporting and accountability variables refer to Regulation of the Minister of Home Affairs (Permendagri) number 113 of 2014 and updated with Permendagri number 20 of 2018 concerning Village Financial Management regulates financial management carried out by village officials. The analytical tool used in data processing is Partial Least Square using Warp PLS software. This study proved that there was a significant influence between the variables of the financial management process (planning, implementing, and reporting) on Accountability. This research has implications for the need for quality financial management processes ranging from planning, implementation and reporting to increasing public confidence in the level of accountability held by village officials.
\end{abstract}

Keywords Financial Management Process, Village Financial Management, Accountability

\section{Introduction}

Village Administration or in Papua Province called Kampung is the smallest government that can manage its finances independently. As a financial manager, the village government must be accountable for finances managed by compiling financial reports. The village government has three main sources of funds, namely from the central government through the Village Fund, the PROSPEK Fund from the Papua Provincial Government and the Village Fund Allocation from the Regency/City to the village. The amount of funds managed can reach 2 billion per year based on the three receipts of these funds. Apart from that, the village government also has Village Original Income derived from business activities, community participation or another village income.

Funds received by the village need to be managed properly starting from planning, implementation, administration, and reporting. Village officials must manage it according to regulations in order to generate trust from the village community. Regulation of the Minister of Home Affairs (Permendagri) number 113 of 2014 and updated with Permendagri number 20 of 2018 concerning Village Financial Management regulates financial management carried out by village officials. Good village financial management will increase the existing development in the village and ultimately enhance good governance. In its use, the village fund manager carries out planning, budgeting, implementation and accountability for funds and will be supervised by village meetings [1-5]. 
Financial management planning is a planning of village government revenue and expenditure in the fiscal year relating to what is budgeted in the Village Revenue and Expenditure Budget. Good planning is a planning process that involves the entire village community and is formulated based on program priorities that will solve the village problem as a whole. In the implementation of planned activities, village financial managers need to manage funds carefully and avoid budget leakage that has not gone through prior planning. The implementation of Village financial management is the income and expenditure of the Village which is carried out through the Village Treasury account at the designated bank. Reporting is the process of submitting the Village Budget implementation report and the Activity Realization Report submitted by the Village to the Regent or Mayor through the district head. Village fund reporting ensures good accountability so that good financial governance can be achieved. There needs to be monitoring and evaluation in the implementation of development in the village so that we can find out the weaknesses and achievements of the village programs that have been made. Financial reporting based on Government Accounting Standards is one aspect of improving good governance [6-8]. This study was intended to prove that the village financial management process, namely planning, implementing and reporting, would increase accountability which is one of the elements in good governance.

\section{Literature Review}

\subsection{Stewardship Theory}

Ramly et al. [9] found that the allocation of village funds has not been able to increase the potential of village resources. In a study in Jayapura District, Rasmi et al. [10] found that the accounting and accountability systems of village heads have not been able to improve village financial management. Several other studies have found that the implementation of village financial management is constrained by a lack of human resources for financial management [11-16]. Stewardship theory is a theory that could be used to explain phenomena related to village financial management. The manager as the chosen person is believed to be able to manage the organization well and be responsible for the community who chooses him to lead the organization. Therefore, for public sector organizations such as villages, the theory that can explain the financial management process of accountability as one of good governance is stewardship theory. This theory describes a management situation not motivated by individual goals but rather by the main goals of the organization he leads. This theory assumes that there is a strong relationship between organizational satisfaction and success. Organizational success illustrates the maximum mutual benefit between principals and management [17].

The implication of stewardship theory in this research was that village officials tried to carry out the trust given by the community as well as possible because the community has chosen them to become leaders and also the Village Consultative Body as representatives of the people in overseeing the running of the government. Therefore, village officials would carry out village financial management starting from planning, implementation and reporting in accordance with applicable regulations in order to increase their accountability to the community led.

\subsection{The Effect of Planning to Accountability}

Village financial management planning begins with planning carried out at the village community level to explore community aspirations in proposing priority programs that are urgently needed in village development. A good village planning forum that can accommodate community aspirations will improve Good governance [18]. Planning increases community coherence and increases aspirations in village development [19]. In addition, planning can also prevent or reveal violations of public authority [20]. Therefore, it could be hypothesized that:

Hypothesis 1: Planning had a positive effect on accountability

\subsection{The Effect of Implementation to Accountability}

The implementation of village financial management is related to the process of income and expenditure of village funds for activities carried out at a certain time. The implementation of programs or activities in the form of receiving funds includes obtaining village income from both the central government in the form of Village Funds, the provincial government through PROSPEK funds, and through the district government through the Village Fund Allocation. In addition, the village's original income can be obtained through activities carried out by the village government to generate income. The implementation of programs or activities in the form of expenditure for goods and the construction of village facilities and infrastructure in order to create community welfare is carried out in the expenditure of village finances.

Implementation in village financial management must be carried out as well as possible following the standards that have been planned by the officials and the village community together. Negligence or violations in village income and financial expenditures will cause community distrust to village officials. The process of implementing activities must be known by the community so that it can increase community trust in village development [21]. Lack of synergy between the apparatus and the Village Consultative Body in the implementation of activities can lead to inadequate implementation of activities due to lack of control [6]. Therefore, it could be hypothesized that: 
Hypothesis 2: Implementation had a positive effect on accountability

\subsection{The Effect of Reporting to Accountability}

The reporting process is a crucial process that most determines the management of village finances. With good reporting, the community will assume that the finances used in village development have been implemented in accordance with the planning and implementation stages. Therefore, reporting will increase accountability which is a part of good governance in village financial management. The information contained in financial reports is a document provided to the public as a form of transparency [22]. Therefore, it can be hypothesized:

Hypothesis 3: Reporting had a positive effect on accountability

\section{Method}

This research was a causal study that examined the variables of planning, implementing and reporting of villages financial information to one aspect of good governance in the public sector which is accountability. This research was expected to produce policies related to the budgeting, implementation and reporting processes that occur in the village government. The research was conducted from May to October 2019 in Sentani District, Jayapura Regency. The number of respondents collected were 20 people from Yahim Village, 20 Yobeh Villages, 20 Sereh Villages and 18 Ifaar Besar Villages.

The source of this research is using primary data. Primary data are data obtained from the first source either from individuals, such as the results of interviews or the results of collecting questionnaires. Primary data in this study were obtained from interviews and questionnaires distributed to village officials, and the respondents' answers were recorded. The interview used in this study is a structured interview. Structured interviews were interviews where the interviewer had a list of questions addressed to the village financial management apparatus.

The unit of analysis in this study was the village financial manager in Sentani District, Jayapura Regency. Sentani District is the capital of Jayapura Regency which has become a barometer of the development and improvement of the economy in this district so that it becomes a good district to be the object of village financial research. The population in this study were village financial management officers in Yahim Village, Yobeh Village, Sereh Village and Ifaar Besar Village. The sampling technique was purposive sampling, namely village financial managers.

The variable in this study was the variable Accountability as the dependent variable and the process of producing financial information, namely the planning, implementation and reporting variables as independent variables. Variable indicators were taken based on the regulation of Ministry of Home Affairs Number 20 of 2018 concerning Village Financial Management.

The accountability variable is one of the principles of Good Governance which refers to the actions taken by the village financial managers entrusted by the community in responding to the expectations given to them in relation to the programs implemented in the village by the village financial management apparatus. The accountability indicator consists of five measurement indicators taken from the regulation of Ministry of Home Affairs No. 20 of 2018. The scale used was a five-point Likert scale with the number 1 indicating strongly disagree with the statements put forward and number 5 indicating strongly agree with the statements stated in the instrument. The indicators of accountability were as that the village chief implements the principle of accountability, made administrative accountability reports and reporting.

The planning variable is one of the processes in village financial management which is the preparation of a program that will be implemented within a certain time. Planning indicators consist of five measurement indicators taken from the regulation of Ministry of Home Affairs No. 20 of 2018. The scale used was a five-point Likert scale with the number 1 indicating strongly disagree with the statements put forward and the number 5 indicating strongly agree with the statements stated in the instrument.

Implementation variable is one of the processes in village financial management that carry out activities that have been prepared by village officials and communities in planning according to program criteria. The Implementing Indicator consists of five measurement indicators taken from the regulation of Ministry of Home Affairs No. 20 of 2018. The scale used was a five-point Likert scale with the number 1 indicating strongly disagree with the statements put forward and the number 5 indicating strongly agree with the statements stated in the instrument.

Reporting Variable is one of the processes in village financial management that records the results of program implementation and finance which will then be made in the form of reports on the results of activities and reports on the use of village funds in accordance with the programs that have been implemented. The Reporting indicator consists of five measurement indicators taken from the regulation of Ministry of Home Affairs No. 20 of 2018. The scale used is a five-point Likert scale with the number 1 indicating strongly disagree with the statements put forward and the number 5 indicating strongly agree with the statements stated in the instrument.

The data analysis in this study used the Structural Equation Model (SEM) approach with the Partial Least Square (PLS) method used the PLS 5.0 warp software. This method was first coined by Wold as a general method for estimating the path model using a latent construct with multiple indicators. PLS is an indeterminacy factor for a 
powerful analysis method because it does not assume that the data must be measured with a certain scale and a small sample size [23].

\section{Result}

The results of descriptive statistics showed that more than $90 \%$ of respondents agreed on statements related to the financial management process starting from planning, implementation and reporting in accordance with the indicators in the regulation of Ministry of Home Affairs No. 20 of 2018 concerning Village Financial Management (Figure 1). In the accountability variable, only $27 \%$ of respondents disagreed with the statement that the village government had no difficulty in arranging village administrative accountability.

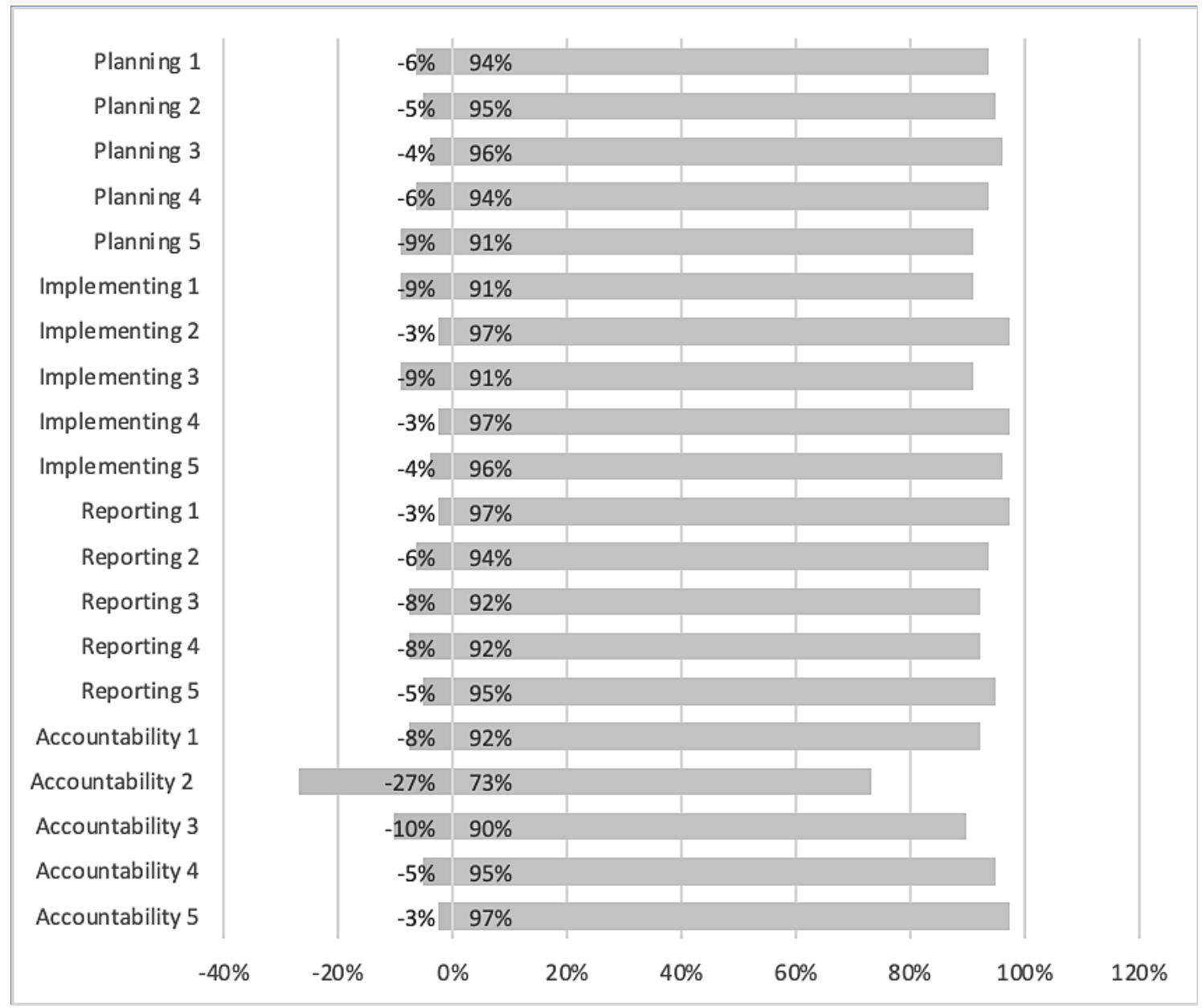

Figure 1. Respondents' Response 
For convergent validity, based on the calculation results, there was one implementation indicator, namely the fifth indicator and one accountability indicator, which was the second indicator with a value below 0.5 that was excluded from the model. After being removed from the model, the indicators of the four variables could be described in Table 1. For discriminant validity, the AVE results are shown in Table 2.

Table 1. Loading Factor

\begin{tabular}{ccccc}
\hline $\begin{array}{c}\text { Loading } \\
\text { Factor }\end{array}$ & Planning & Implementing & Reporting & Accountability \\
\hline $\begin{array}{c}\text { Indicator } \\
1\end{array}$ & 0.690 & 0.752 & 0.640 & 0.649 \\
\hline $\begin{array}{c}\text { Indicator } \\
2\end{array}$ & 0.770 & 0.838 & 0.779 & - \\
\hline $\begin{array}{c}\text { Indicator } \\
3\end{array}$ & 0.859 & 0.810 & 0.830 & 0.819 \\
\hline $\begin{array}{c}\text { Indicator } \\
4\end{array}$ & 0.725 & 0.510 & 0.763 & 0.869 \\
\hline $\begin{array}{c}\text { Indicator } \\
5\end{array}$ & 0.653 & - & 0.575 & 0.755 \\
\hline
\end{tabular}

Table 2. Square roots of AVE

\begin{tabular}{ccc}
\hline No. & Variable & $\begin{array}{c}\text { Square roots of } \\
\text { AVE }\end{array}$ \\
\hline 1. & Planning & 0.743 \\
\hline 2. & Implementation & 0.739 \\
\hline 3. & Reporting & 0.724 \\
\hline 4. & Accountability & 0.777 \\
\hline
\end{tabular}

For composite reliability, the results of composite reliability show that each indicator can measure the variable reliably (Table 3). Meanwhile Table 4 showed the $\mathrm{R}$ square and $\mathrm{Q}$ square.

Table 3. Composite Reliability

\begin{tabular}{cccc}
\hline No. & Variable & $\begin{array}{c}\text { Composite } \\
\text { reliability }\end{array}$ & $\begin{array}{c}\text { Cronbach's } \\
\text { Alpha }\end{array}$ \\
\hline 1. & Planning & 0.859 & 0.794 \\
\hline 2. & Implementation & 0.823 & 0.711 \\
\hline 3. & Reporting & 0.844 & 0.766 \\
\hline 4. & Accountability & 0.858 & 0.777 \\
\hline
\end{tabular}

The model shows that the R-square is 0.182 . This shows that the model has endogenous accountability, which can be explained by $18.2 \%$ by Variable Planning, Implementing and Reporting and $81.8 \%$ from other variables not found in the model. The $\mathrm{Q}$ square value based on the Table below shows that the model has an exogenous predictability that is far from the number 1 .

Table 4. R square and $\mathrm{Q}$ square

\begin{tabular}{cccc}
\hline No. & Model & R square & Q square \\
\hline 1. & Model Accountability & 0.182 & 0.201 \\
\hline
\end{tabular}

Next is the hypothesis test. Based on the calculation of the influence of variables in the first hypothesis, it appeared that the significance value is 0.019 which means that the higher the planning variable, the higher the accountability variable and therefore the first hypothesis was accepted. The results of calculating the influence of variables in the second hypothesis showed that the significance value is 0.039 , which means that the higher the implementing variable, the higher the accountability variable and therefore the second hypothesis was accepted. The results of calculating the influence of variables in the third hypothesis showed that the significance value is 0.020 , which means that the higher the reporting variable, the higher the accountability variable and therefore the third hypothesis was accepted.

Table 5. Direct Effect Testing Results

\begin{tabular}{ccccc}
\hline No. & Direct Effect & Coefficients & $\begin{array}{c}\text { P } \\
\text { values }\end{array}$ & Hypothesis \\
\hline 1 & $\begin{array}{c}\text { Planning } \rightarrow \\
\text { Accountability }\end{array}$ & 0.224 & 0.019 & Accepted \\
\hline 2 & $\begin{array}{c}\text { Implementing } \rightarrow \\
\text { Accountability }\end{array}$ & 0.191 & 0.039 & Accepted \\
\hline 3 & $\begin{array}{c}\text { Reporting } \rightarrow \\
\text { Accountability }\end{array}$ & 0.220 & 0.020 & Accepted \\
\hline
\end{tabular}

The test results showed that the fund management process greatly influences the increase of accountability as an indicator of good governance. Planning had a significant effect on government accountability. This was in line with research conducted by Wicaksana el al. [18]. With good planning, it would be increasingly difficult for officials to commit violations and thereby increase accountability to society. The implementation of activities affected the level of accountability of officials to society. Based on the research results, $97 \%$ of the community felt that the village government apparatus had implemented the principle of transparency in the implementation of village finances and thus they jointly assisted other members in implementing the village fund management program. This was consistent with what Asni et al. [6] that there is a need for synergy among all community members, both village officials and village representatives, so that the implementation of activities can be carried out optimally. With togetherness in carrying out activities, public confidence that village officials act responsibly would be increased [21]. Activity reporting greatly affected the level of accountability. As many as $97 \%$ of respondents said that the reporting process was in accordance with the predetermined structural path. By doing so, they believed that the village head had submitted a good accountability report and increased the perception of the level of good governance towards the village government. This is in line with previous research [23] stating that good financial statement information will increase trust in public sector management, and increase the quality of public service [24].

\section{Conclusions}

The village financial management process starting from 
planning, implementing and reporting affects the level of accountability assessed by the community. With the implementation of a good financial management process, it has created public trust in village officials so that the community believes that the financial manager is responsible for the position entrusted to them. The implication of this research is that village officials need to improve the quality of the financial management process so that good governance in the village can be improved. The limitation in this study is that the accountability assessment is based on self-assessment by village officials so that further research needs to be carried out involving the community or the Village Requirements Board as respondents so that they can assess good governance without individual bias.

\section{REFERENCES}

[1] P. Kazimoto, "Analysis of Village Financial Management Challenges in Arumeru District in Tanzania",International Journal of Research in Social Sciences, Vol. 3, No. 2, pp. 112-118, 2013.

[2] E. D. Siburian, "The Role of Village Revenue and Expenditure Budget in Rural Area Development in Serdang Bedagai Regency”, Jurnal Ekonom, Vol. 17, No. 2. 2014. [in Indonesian]

[3] I. Yuhertiana, T. D. Widajatie, \& F. S. Akbar, "Financial Confusion and Corruption Anxiety: A Good Village Governance Pressure", Simposium Nasional Akuntansi XIX, 2016.

[4] S. Falah, E. R. Marlisa, B. Pangayow, \& I. Ghozali, "Antecedent development of village borders: Testing analysis of factors", International Journal of Civil Engineering and Technology, Vol. 9, No. 8, pp. 654-667, 2018

[5] B. Pangayow, "Gap in Village Financial Report Quality Expectations between Financial Managers and Communities in Sentani District, Jayapura Regency", Journal of Regional Accounting and Finance, Vol. 12, No. 1, pp. 1-11, 2017 [in Indonesian]

[6] F. Asni, Maryunani, Sasongko, D. Budi, "The Management of the Village Fund Allocation as an Instrument towards Economic Independence Village (Case Studies in 2 villages in Siak Regency, Province Riau)", IOSR Journal of Business and Management, Vol. 10, No. 4, pp. 1-9, 2013

[7] T. Kurrohman, "Accountability of planning on village fund allocation in osing community in Banyuwangi", Proceedings of The International Conference on Accounting Studies, 2015

[8] N. W. Rustiarini, \& U. M. Denpasar, "Good Governance in Village Fund Management", Simposium Nasional Akuntansi, 19, pp. 1-18, 2016 [in Indonesian]

[9] A. Ramly, W. Wahyuddin, J. Mursyida, \& M. Mawardati, "The Implementation of Village Fund Policy in Improving Economy of Village Society”, Jurnal Ilmiah Peuradeun, Vol.
6, No. 3, pp. 459-478, 2018

[10] D. Rasmi, A. Salle, \& B. Pangayow, "Analysis of Village Financial Management and Accountability (Empirical Study in Sentani District, Jayapura Regency)", Journal of Regional Accounting and Finance, Vol. 13, No. 1, pp. 83-95, 2018 [in Indonesian]

[11] N. A. Azlina, D. Hasan, \& I. Muda, "The Effectiveness of Village Fund Management (Case Study at Villages in Coastal Areas in Riau)", International Journal of Economic Research, Vol. 14, No. 12, pp. 325-336, 2017

[12] F. Simangunsong, \& S. Wicaksono, "Evaluation of Village Fund Management in Yapen Islands Regency Papua Province (Case Study at PasirPutih Village, South Yapen District)", Journal of Social Science, Vol. 5, No. 9, pp. 250-269, 2017

[13] Kurniawan \& I. Firmansyah, "Problem and Solution of Village Accounting Implementation Using Analytic Networks Process Approach",International Journal of Management and Applied Science, Vol. 4, No. 5, pp. 52-56, 2018

[14] E. Savitri, T. A. Gumanti, A. Andreas, \& V. Diyanto, "The effectiveness of allocated village funds management (A Study in Pelalawan District, Riau Province, Indonesia)" Jurnal Aplikasi Manajemen, Vol. 16, No. 4, 722-730, 2018

[15] Y. Kurniawati, \& B. Pangayow, "Effect of financial management accountability for village fund allocations, village policies and village institutions on community welfare (Study in Kampung Sentani District, Jayapura Regency)" Journal of Regional Accounting and Finance, Vol. 12, No. 2, pp. 77-87, 2017 [in Indonesian]

[16] K. Wonar, S. Falah, \& B. Pangayow, "The Effect of Village Apparatus Competence, Compliance with Financial Reporting and Internal Control Systems on Fraud Prevention with Moral Sensitivity as Moderation Variables" Journal of Accounting, Auditing, and Assets (AAA), Vol. 1, No. 2, pp. 63-89, 2018

[17] M.H. Saad, Arifuddin, \& R.A. Damayanti, "The effects of competence and internal control systems on the accountability of village financial management with organizing commitment as moderation variables", Global Scientific Journals, Vol. 8, No. 1, pp. 332-338, 2020

[18] F. G. Wicaksana, R. A. Trihatmoko, D. Suhardjanto, \& H. Murtini, "The Regulation on Village Governance in Indonesia: Efficient Contracting in Agency Theory", Journal of Public Administration and Governance, Vol. 9, No. 2, pp. 110-137, 2019

[19] F. A. Nasution, Erlina, \& Rujiman, "The Role of Village Funds to the Development Area in the Sub-District of West Bilah, Labuhanbatu Regency, North Sumatera, Indonesia", International Journal of Progressive Sciences and Technologies, Vol. 6, No. 1, pp. 221-227, 2018

[20] A. F. Basuki, R. D. Wahyunengseh, K. Setyowati, "Accountability and democratization of village budget: how village government in Indonesia respond to this?" Advances in Social Science, Education and Humanities Research, Vol. 241, pp. 71-76, 2018

[21] M. L. Iznillah, \& Y. M. Basri, "Analysis of transparency and 
accountability of village fund management in Bengkalis Sub-district", Journal of Economics, Business, and Government Challenges, Vol. 1, No. 2, 135-142, 2018

[22] Y. A. Temenggung, "Rural Financial Management In Perspective Law No. 6 Of 2014 Concerning The Village" International Journal of Social Sciences, Vol. 43, No. 1, pp. 42-54, 2016

[23] Ghozali I. (2014). Structural Equation Modelling Metode Alternatif dengan Partial Least Squares (PLS). Semarang:
Badan Penerbit Universitas Diponegoro

[24] Javed, M. \& Zhuquan, W, “Analysis of accounting reforms in the public sector of Pakistan and adoption of cash basis IPSAS", Universal Journal of Accounting and Finance, Vol. 6, No. 2, pp. 47-53, 2018.

[25] Gabrielli, G. \& Medioli, A, "An Overview of Instruments and Tools to Detect Fraudulent Financial Statements", Universal Journal of Accounting and Finance, Vol. 7, No. 3, pp.76-82, 2019. 